\title{
Effects of a Mathematics Cognitive Acceleration Program on Student Achievement and Motivation
}

\section{Situating the Study in Tongan School Education}

Tonga's educational system was initially modelled after that of England, but it has since evolved to become more compatible with Tonga's social and economic structure (Ministry of Education and Training, 2014). Religion is deeply integrated in Tongan society and in the education system as well with the result that the Tongan secondary educational system heavily relies on a range of Christian religious schools. Approximately $28 \%$ of the student population attends government schools and the remaining $72 \%$ attends church schools (Vivier, 2013). Different from many other education systems where some private schools are among the best schools, the Tongan government schools are regarded as the best secondary schools in the country because they always select students with the highest scores in the Secondary School Entrance Examination (SSEE). The students with low scores in the SSEE enter the church-affiliated high school of their choice (Uata, 2002).

In recent decades, there has been a growing concern over the low level of mathematics performance in Tongan secondary schools (Fasi, 1999; Manu, 2005). The Tonga National Examination Unit (TNEU) has reported that students perform poorly in mathematics compared to other subjects. For example, in the 2013 Tonga School Certificate (TSC) examination for 16 year olds, only $48 \%$ of students passed in mathematics compared to $86 \%$ in accounting, 78\% in economics and 68\% in English (Ministry of Education and Training, 2014). The mathematics chief examiner's report indicated that students tend to do well on questions that require simple recall of information but have difficulties in answering questions that demand understanding and application of concepts (Ministry of Education and Training, 2014). 
Many aspects of Tongan education are seen as contributing towards students' poor performance, including inadequate teaching and learning resources (Ministry of Education and Training, 2014; Uata, 2002), a shortage of qualified teachers to teach mathematics (Tatafu, Booth, \& Wilson, 2000), students' low socioeconomic circumstances (Uata, 2002), an examination system that reinforces rote learning, and the mismatch between students' cognitive ability and the cognitive demands of the school mathematics curricula (Pohiva, 2014). In an effort to improve students' performance, the Ministry of Education in Tonga has developed several curricular modules, placing emphasis on teaching thinking skills in mathematics. Yet, teaching for enhancing mathematics thinking skills has been problematic in many instances, especially in the case of controlling variables, interpreting data, conceptualising and problem solving (Ministry of Education and Training, 2014; Pohiva, 2014). Just as is the case in many parts of the world, Tongan mathematics educators are looking for approaches that promote the development of mathematical thinking skills in order to improve students' mathematics performance.

One approach that has been adopted successfully in many countries is the use of instructional materials that promote cognitive development and raise students' reasoning levels, thereby enhancing their ability to use higher order thinking skills. The instructional approach known as 'Cognitive Acceleration in Mathematics Education (CAME)' (Adhami \& Shayer, 2007) was considered as a possible way to address the need of Tongan mathematics education, and this instructional approach is the focus of this research.

\section{Effects of CAME and CASE Programs on Cognitive Development and Achievements}

Shayer, Adey and Yates $(1989,2001)$ developed curriculum materials for an instructional program known as the Cognitive Acceleration in Science Education (CASE) program, a cognitive intervention program that fosters and accelerates students' cognitive science 
development in normal school settings in England. The CASE program has made considerable impact on science learning and examination performance in many high schools in England, suggesting that it is possible to improve students' higher order thinking skills and advance their cognitive development towards what Piaget termed as 'formal operational thinking' (Adey, 1999).

Following publication of the original research findings (Adey \& Shayer, 1993, 1994) and the subsequent media attention, interest in CASE developed rapidly inside and outside of England. Its theory and practical approaches were adopted in other disciplines, including mathematics, technology, geography, as well as in programs for younger children in early childhood and middle primary years (Adey, Robertson, \& Venville, 2002; Adhami \& Shayer, 2007; Backwell \& Hamaker, 2003; Shayer \& Adhami, 2010).

For mathematics, the Cognitive Acceleration in Mathematics Education (CAME) program was launched in England. The aim of the CAME program was to contribute to the teaching of mathematics in the lower secondary school, where students have a window of opportunity for prompt transition from concrete thinking to abstract thinking. A set of CAME lessons, called Thinking Maths (Adhami \& Shayer, 2007), consists of 30 activities which provide cognitive stimulation using challenging classroom tasks with an emphasis on big ideas in mathematics. The program was implemented over two years in Years 7 and 8 (11-13 years of age).

Once the early CAME research had been completed, several reports have been published on the effects of the CAME strategies on children's cognitive development, students' achievement and teachers' teaching pedagogy (for summaries of studies, please refer to Shayer \& Adhami $(2007,2010))$. After the success of the CAME program in England, the program with its theoretical and practical approach was adapted and successfully tried out in other places in the world including Hong Kong (Mok \& Johnson, 
2000), Ireland (Kerridge, 2010), Nigeria (Olaoye, 2012), Singapore (Hong, 2010), and Finland (Aunio, Hautamäki, \& Van Luit, 2005).

\section{The Theory and Pedagogy of the CAME Program}

For the development of curricular materials and teaching methods, the framework of the CAME intervention program draws heavily from the cognitive development theory of Piaget and the socio-cultural psychology of Vygotsky (Adhami \& Shayer, 2007). Piaget's emphasis on the patterns of children's thinking depending on their developmental stages provided the basis of curricular material development. The strength of Piaget's theory is the description of children as active learners and his rich description of what children can do and cannot do at various ages or levels. This view of learners forms a basis for curriculum planning (Adey \& Shayer, 1993). On the other hand, Vygotsky's notion of the Zone of Proximal Development (ZPD) which supports teaching ahead of the child's development (Vygotsky, 1986) is the critical feature of the CAME pedagogy. Vygotsky argued that the school should not just present children with learning at the level of understanding with which they can cope; 'instruction is good only when it proceeds ahead of development, when it awakens and rouses to life those functions which are in the process of maturing' (Shayer, 2003, p. 468). Through professional development and the coach visiting during the intervention, teachers learn to become aware of and easily identify their students' levels of cognition so they can adjust classroom activities beyond their current capabilities, to stimulate new ways of thinking without going too far beyond what the students are capable of in a given context.

Based on the theories of Piaget and Vygotsky, the CAME teaching approach entails five working principles known as 'pillars' of cognitive acceleration in each lesson, namely concrete preparation, cognitive conflict, construction, metacognition and bridging. Cognitive preparation involves the teacher portraying the nature of the problem, setting the scene and elucidating the vocabulary pertinent to the lesson. Students need to know and be familiar with 
the context of the problem as well as the terminologies that are used in the activity. Cognitive conflict refers to students observing an event which does not align with their view of reality; the assumption is that the students are compelled to reconsider (and possibly change their conceptual framework) (Maume \& Matthews, 2000) and engage their minds to make sense of the experience. In some cases, students need to think and talk about the abstract idea or model to explain the given phenomenon. Piaget described that process as 'adaptation' in which children modify their behaviour and cognitive structures so they can cope with the new environment or experience. Adaptation is seen to happen through the interaction of two corresponding processes of assimilation and accommodation. During assimilation, a child modifies the information so that it can fit with her/his cognitive structures. Accommodation happens when the information cannot be easily assimilated in the child's cognitive structures. This brings about cognitive conflict. According to Piaget, in order to resolve the conflict, the cognitive structure of the child changes so that the new information can be assimilated. Simply, such cognitive conflict is considered the driver of cognitive growth because a mental struggle is required by the students to move beyond their current ways of thinking.

The principle of construction is based on Vygotsky's notion of Zone of Proximal Development (ZPD) (Vygotsky, 1986). Once cognitive conflict has been generated, the students have to resolve the conflict by reasoning mediated by peers, by the teacher or by a combination of both. The process of construction involves oral discussion around new ideas, exploring them through group discussions, seeking explanations and justifications. In this CAME intervention, construction is referred to the periods of small group activity in the classroom, where students construct, share, develop and discuss meaning(s). The whole class discussion periods are used for all groups to listen, contribute their group's ideas and for individuals to refine and develop their own understanding. 
While students carry out investigations, the process of metacognition takes place. Students are taught to become aware of their own thinking and how others were thinking when they discussed or solved the problem. Also students need to be aware of what they learned that is different from what they understood and could do prior to the lesson. In this CAME program, metacognition brings "thinking about thinking" (Frith, 2012) into the classroom dialogue and requires time during the lessons for teachers to bring out the best of students' problem-solving strategies and reflect on their errors as well as alter their thinking patterns. With teacher-student dialogue during the problem solving process, teachers learn to be aware of not only knowing what and when to monitor, but also how to monitor and evaluate the students' thinking strategies.

Bridging is the final pillar and link in this chain of developing, abstracting, and generalising reasoning. The teacher expands the problems that students have undertaken to show where similar problems occur in other areas of the mathematics curriculum or in everyday life activities. Students are required to make explicit the strategies that they have developed and imagine how they can learn more by abstract thinking and reasoning.

Sometimes the pillars of the CAME program are perceptible as being discrete and sequential within a particular lesson, albeit much of the time they are profoundly integrated. Anecdotal evidence suggests that as teachers become confident in utilizing the five pillars, they adopt them in their regular mathematics lessons and provide opportunities for students to draw on the problem-solving strategies and ways of thinking developed during the CAME lessons (Shayer \& Adhami, 2007). This teaching approach complements the other ingredients in students' mathematical experience and significantly raises students' thinking capacity, creating a stable basis for higher achievement in later years of schooling. Based on the evidence from previous research, the effects of the CAME program has shown to have longterm effects on students' achievement and learning (Shayer and Adhami, 2007). 


\section{Motivation and Self-regulation in Mathematics Learning}

Even though cognitive aspects are important, motivation and self-regulation also play an important role in students' learning. Many studies on motivational beliefs have suggested that there is a positive relationship between self-regulation, motivational beliefs and academic performance (Mega, Ronconi, \& De Beni, 2014; Velayutham, Aldridge, \& Fraser, 2011; Wolters, 1999). Pekrun (1992) argued that lack of proper consideration of students' motivational beliefs and self-regulation when engaged in academic tasks will profoundly impact upon their cognitive strategies of learning and hence their academic achievement.

For example, with their trial experimental CASE intervention findings, Adey and Shayer (1993) have been criticised for failing to give an adequate account of why some students learned and achieved, whereas others did not. According to Leo and Galloway (1996), motivational style might provide the missing explanation for a given reason. Motivational style, as described by Leo and Galloway, is an individual variable and refers to the type of motivation students bring to academic situations. They claimed that the question of students' reasons for learning had not been considered in the program. Similarly, Pintrich (2000) established that students with higher motivation skills are more likely to be academically self-regulated and are likely to change their thinking processes. When the teaching and activities are matched with the students' motivational styles, there is a possibility that the student can regulate himself/herself during the problem-solving processes to achieve the desired goal.

The CAME program in Tonga has recognised these issues and tried to include learning attitudes in the program design and implementation. Though the CAME program is focused on a significant national problem in Tonga of falling achievement in mathematics, this paper also examined how the CAME program with its selected thinking lessons and teaching pedagogy impacts on students' attitude toward mathematics. 


\section{Purpose of the Study}

The purpose of this study was to investigate the effect on Year 8 (Form 2) mathematics students of implementing the CAME program in secondary schools in Tonga. The effects of the program were determined by examining the differences in students' responses to two instruments that evaluated students' content knowledge and attitudes. This study was guided by two research questions (RQs):

RQ 1: To what extent does the CAME program change Tongan Year 8 (Form 2) students' academic achievement in mathematics?

RQ 2: What are the Year 8 (Form 2) students' motivation and self-regulation levels as a result of participating in the learning of mathematics in the CAME program?

\section{Research Methods}

This research used a quasi-experimental design with multiple data sets (Cohen, Manion, \& Morrison, 2011) that was conducted in four secondary schools in Tongatapu, the main island of Tonga. The study utilised both quantitative and qualitative data including a pre-test and a post-test, interviews, and classroom observations. Using a mixed-methods sequential explanatory design (Creswell \& Clark, 2008), this study integrated the strengths of both the quantitative and qualitative data.

To assess participants' content knowledge, this study used a pre-test (Numeracy Reasoning Task 1 (NRT1)) and a post-test (Numeracy Reasoning Task 2 (NRT2)). For students' attitudes and motivation, this study adopted the Students' Adaptive Learning Engagement (SALE) questionnaire as pre- and post-surveys, followed by semi-structured reflective interviews to assess the students' experiences and perspectives on participating in the CAME program. This quasi-experimental design with comparison and experimental schools was set up using the schedule shown in Table 1 . 
Table 1

The CAME program study schedule

\begin{tabular}{|c|c|c|}
\hline Time Frame & Experimental Schools & Comparison School \\
\hline February, 2014 & $\begin{array}{ll}\text { - } & \text { Pre-test }- \text { NRT } 1 \\
\text { - } & \text { Pre-test - SALE } \\
\text { - } & 1^{\text {st }} \text { Teacher Professional } \\
& \text { Development }\end{array}$ & $\begin{array}{ll}\text { - } & \text { Pre-test - NRT } 1 \\
\text { - } & \text { Pre-test - SALE }\end{array}$ \\
\hline March - October, 2014 & $\begin{array}{l}\text { - Form 2 (Year 8) used 16 CAME } \\
\text { lessons + Regular curriculum } \\
\text { - Classroom observations + } \\
\text { coaching }\end{array}$ & $\begin{array}{l}\text { - } \quad \begin{array}{l}\text { Form } 2(\text { Year } 8) \text { used } \\
\text { their regular curriculum }\end{array} \\
\text { - } \quad \text { Classroom observations }\end{array}$ \\
\hline May, 2014 & $\begin{array}{l}\text { - } 2^{\text {nd }} \text { Teacher Professional } \\
\text { Development }\end{array}$ & \\
\hline August, 2014 & $\begin{array}{l}\text { - } \quad 3^{\text {rd }} \text { Teacher Professional } \\
\text { Development }\end{array}$ & \\
\hline October ( $4^{\text {th }}$ week $), 2014$ & $\begin{array}{ll}\text { - } & \text { Post-test - NRT } 2 \\
\text { - } & \text { Teachers' interviews }\end{array}$ & $\begin{array}{ll}\text { - } & \text { Post-test }- \text { NRT } 2 \\
\text { - } & \text { Teachers' interviews }\end{array}$ \\
\hline $\begin{array}{l}\left.\text { November ( } 1^{\text {st }} \text { week }\right) \text {, } \\
2014\end{array}$ & $\begin{array}{ll}\text { - } & \text { Post-test - SALE } \\
\text { - } & \text { Students' interviews }\end{array}$ & $\begin{array}{ll}\text { - } & \text { Post-test }- \text { SALE } \\
\text { - } & \text { Students' interviews }\end{array}$ \\
\hline
\end{tabular}

\section{Teachers' Professional Development (PD)}

There is a substantial body of research internationally which affirms that quality education is not possible without quality teaching (McGregor \& Gunter, 2001). Teachers, who are at the heart of every education system, learn about teaching plans and strategies during their initial preparation. The ongoing professional development of teachers is a central element of the process and dynamics of achieving the goals and targets relating to quality, access and equity in education.

The design of the professional development (PD) in this study drew on the work of Adey, Hewitt, Hewitt, and Laudau (2004) as shown in Figure 1. The PD training was started with a one-day in-service workshop with all the Form 2 (Year 8) mathematics teachers from the experimental schools prior to the implementation of the CAME program. In this one-day 
PD training, teachers received the CAME materials that included activities of lessons and worksheets. In addition, the first author introduced the CAME teaching approach with the role of the teacher in the development of mathematical reasoning by students, rather than providing fragmentary teaching. The training was based on the Piagetian ideas of cognitive conflict and equilibration, and on the Vygotskyan ideas of metacognitive reflection and social construction where social practices need to be developed not only to engage learners in activities in which they acquire knowledge, but also to engage them in activities that further their intellectual development.

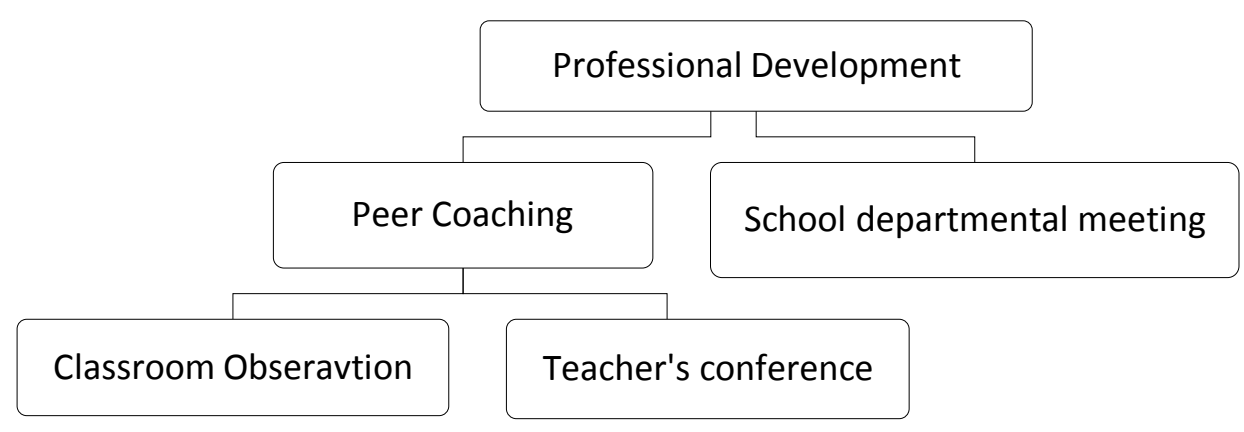

Figure 1. An outline of the CAME professional development for the experimental schools

Following the first PD, the first author conducted 'peer coaching' visits where he had the opportunity to hold classroom observations and meet with the participating teachers to discuss their progress in practicing CAME lessons as well as aspects that needed to be improved for the next lessons. However, the second and third professional development sessions included all the experimental school teachers during Terms 2 and 4.

In each PD training session, teachers discussed the CAME lessons that they recently taught to compare their experiences and share their skills; the approach was designed to help other teachers to improve their teaching. A volunteer had an opportunity to teach one lesson during the training while others observed and took notes for later discussion and feedback. The first author then initiated the discussion of the relevant theoretical aspects of the CAME approach followed by further discussion with the rest of the teachers. 


\section{Participants}

The experimental group consisted of 219 Form 2 (Year 8) students and seven teachers from three schools that were involved in the CAME program. The comparison group consisted of 119 Form 2 (Year 8) students and four teachers from a school that was not involved in the CAME program. All the four schools were church-affiliated schools with most students from low socioeconomic families in outlying rural villages and farming communities of Tongatapu. Students attended these church schools because they were not accepted in government secondary schools due to their low achievement scores in the Year 6 Tonga Secondary School Entrance Examination (SSEE). The participating schools were all comparable (see Table 2), with students of similar age group (11 - 14 years), with equivalent study resources and teachers with similar experience and teaching skills. Sixteen of these students (twelve from the experimental schools and four from the comparison school) were randomly selected to be interviewed.

Table 2

Comparison of four participating schools

\begin{tabular}{|c|c|c|c|c|}
\hline $\begin{array}{l}\text { Demographic } \\
\text { information }\end{array}$ & School 1 & School 2 & School 3 & School 4 \\
\hline CAME intervention & Yes & Yes & Yes & No \\
\hline $\begin{array}{l}\text { Enrolment in Form } 2 \\
\text { Mathematics in } 2014\end{array}$ & 70 & 78 & 98 & 141 \\
\hline $\begin{array}{l}\text { No. of Form } 2 \\
\text { mathematics classes }\end{array}$ & 4 classes & 4 classes & 5 classes & 7 classes \\
\hline $\begin{array}{l}\text { SSEE minimum } \\
\text { entrance scores }\end{array}$ & 160 & 160 & 160 & 165 \\
\hline $\begin{array}{l}\text { No. of Form } 2 \\
\text { mathematics teachers }\end{array}$ & 2 & 2 & 3 & 4 \\
\hline $\begin{array}{l}\text { Form } 2 \text { teachers' } \\
\text { qualification }\end{array}$ & $\begin{array}{l}\text { - BA(1) } \\
\text { - Diploma (1) }\end{array}$ & - $\operatorname{BSc}(2)$ & $\begin{array}{l}\text { - BSc (2) } \\
\text { - Diploma (1) }\end{array}$ & $\begin{array}{l}\text { - BSc (2) } \\
\text { - Diploma (2) }\end{array}$ \\
\hline Students-teacher ratio & $35: 1$ & $36: 1$ & $33: 1$ & $35: 1$ \\
\hline School location & Rural area & Rural area & Rural area & Rural area \\
\hline
\end{tabular}




\section{Instruction in the CAME Schools}

The CAME intervention used in this study is similar to the CAME program that originated in England. However, due to the limited time of this study, the intervention involved only 16 lessons, adapted and modified from Thinking Maths (Adhami \& Shayer, 2007) and were delivered over eight months (March - October, 2014). Usually each activity was intended to replace an ordinary mathematics lesson every two weeks. Each lesson focused on specific reasoning patterns (or schemata) including controlling variables, ratio and proportionality, probability and correlation, and the use of abstract models to explain and predict. Within these 16 lessons, some of the lessons spiralled through increasing levels of complexity that were related to the reasoning patterns.

Each of the 16 lesson activities were structured into three episodes, and each episode consisted of three teaching phases. The episodes were designed so that students from a wide range of initial cognitive achievement could each make some progress during each lesson. However, the timing for each episode was suggested assuming students were at the level of mid-range achievement. The three teaching phases for each episode emphasize the five theoretical principles of Piaget and Vygotsky (see Table 3).

Table 3

Teaching phases with theoretical principles (pillars)

\begin{tabular}{ccc}
\hline No. & Teaching Phases & Theoretical Principles \\
\hline 1. & Whole class concrete preparation & Concrete Preparation \\
2. & Small group collaborative learning & Cognitive Conflict, Construction \\
3. & Whole class collaborative learning & Construction, Metacognition, Bridging \\
\hline
\end{tabular}

In the first phase (8-10 mins), the focus was on 'whole class concrete preparation' where the mathematical context of the activity was introduced at a level that could be understood by all students. The teacher's role was to show the task to the students and then 
allow them to describe or re-express what the task was and suggest possible ways to achieve it. The teacher could record students' answers on the board and encourage questions which could help them understand what they will do in phases 2 and 3.

In the second phase, called 'small group collaborative learning' (at least 10 mins), students in groups of two to four attempted the first worksheet with the intention that each group would have something to contribute in the next phase. In this phase, students developed ideas that they could show and explain to others. The given worksheet was to focus on challenging (it was not given any value of assessment) the students' thinking, which allowed them to present all the possible ideas that they thought were related to the solution of the task. The role of the teacher was to observe each group as they worked and remembered what ideas they were generating in order to invite groups to present their work in a logical order in the next phase.

In the third phase, referred to as the 'whole class collaborative learning', students' solutions from each group were shared with the whole class (at least 10 mins). In this phase, each group reported to the rest of the class the findings of their group work and discussions. In addition, students or groups could express their difficulties to the whole class, allowing the other groups to contribute to and benefit from the discussion. Typically, phase 3 led naturally to the next episode with the learning agenda set usually at a higher academic level. All the episodes and phases were designed to facilitate an extensive range of thinking and challenges. An episode of each of the three phases of CAME is shown in Figures A and B of the Online Supplementary Materials (OSM). In Figure A, the lesson activity has been structured into episodes with wide levels of attainment that the students can achieve at the end of the activity. Figure B illustrates how the episode is broken down into phases to help the teachers manage their teaching by applying the principles of Concrete Preparation, Cognitive 
Conflict, Construction, Metacognition, and Bridging in their teaching practice and engaging the students in their learning of mathematics.

The 16 CAME lesson activities (see Table 4) are intended as components of the school curriculum, with one CAME lesson replacing one regular mathematics lesson every two weeks over the intervention. During the intervention, teachers and participating CAME schools were asked to include these activities in their scheme of work and modify the schedule to suit their scheme for the year. All these selected lessons were connected to real Table 4

Lesson activities with the curriculum links

\begin{tabular}{|c|c|c|c|c|}
\hline No. & Lesson Activity & Curriculum link & Term & Week \\
\hline 1. & Number lines galore & Number System and properties, number lines & 1 & 3 \\
\hline 2 & Setters and solvers & Place value and Number operations & 1 & 5 \\
\hline 3. & Sets and subsets & $\begin{array}{l}\text { Integers, multiple, factors and primes, angle } \\
\text { properties of triangles and quadrilaterals }\end{array}$ & 1 & 7 \\
\hline 4. & Ladders and slides & Numbers - Multiplicative relations & 1 & 9 \\
\hline 5. & Algebra 1 and $1 \mathrm{a}$ & Numbers and algebra - Reasoning and justification & 2 & 2 \\
\hline 6. & Text 'n' talk & Multiplication and algebra & 2 & 4 \\
\hline 7. & Which offer shall I take? & Algebra, symbols, algebra - graphing & 2 & 6 \\
\hline 8. & Framed tiles & $\begin{array}{l}\text { Area and perimeter in standard and uniform non- } \\
\text { standard units }\end{array}$ & 2 & 8 \\
\hline 9. & Rectangular functions & Area and perimeter - aspects of continuity & 3 & 2 \\
\hline 10. & Decontamination & $\begin{array}{l}\text { Angle measurement, scale measurement, bearing } \\
\text { and LOGO conventions }\end{array}$ & 3 & 4 \\
\hline 11. & Tents & Measurement, $\pi$ ratio and geometric reasoning & 3 & 6 \\
\hline 12. & Circle functions & Area and circumference & 3 & 8 \\
\hline 13. & Furniture design & Median and range, measurements of lengths & 4 & 2 \\
\hline 14. & Sam and the newspaper & Statistics - collecting and analysing data & 4 & 4 \\
\hline 15. & Three dice & Probability - experimental and theoretical & 4 & 6 \\
\hline 16. & Functions & Multiplicative relations and graphs & 4 & 8 \\
\hline
\end{tabular}


life activities and were also linked to the current curriculum of the participating schools. The lessons provided an opportunity for the teacher to build a new classroom culture where enquiry, collaborative learning and sharing of ideas were dominant themes and learning mathematics was no longer seen as an individual activity, where students were expected to be trained in the application of formal rules and procedures.

\section{Instruction in the Comparison School}

The comparison group students were instructed based only on the mathematics curriculum provided by the government and teachers used the teaching strategies that they normally practiced in their classrooms. Hence, the teachers were not really supported to use students' group discussions, and their teaching practices were mainly the teacher's lecture and writing of notes. Teachers preferred this type of practice as they managed to complete the syllabus as required by the administrators.

At the beginning of the year, the comparison school was given the same 'scheme of work' as that given to the experimental schools. This scheme of work had the list of all the Form 2 mathematics topics and contents in sequence as well as information on how to cover them throughout the academic year. The teachers in the experimental schools were required to teach these topics and contents based on the CAME teaching approaches, while the teachers from the comparison school followed taught using their traditional ways 'blackboard and chalk'. In addition, in the scheme of work, the date for each CAME lesson activity was highlighted, which meant that on that day the experimental schools switched to the CAME lesson while the comparison school continued with the normal lesson of the regular curriculum.

\section{Data source and instruments}

Numeracy Reasoning Tasks 1 and 2 (NRT 1 and NRT 2). Numeracy Reasoning

Tasks 1 and 2 are instruments that were constructed by the first author to ascertain the 
mathematics content knowledge of the Form 2 students. These two instruments, both consisting of 20 items (see Appendices 1 and 2 in the OSM), were administered to both groups as a pre-test prior to commencing instruction and as a post-test at the end of instruction after eight months. The items in both the NRT1 and NRT2 were selected from the Tonga Form 2 Mathematics Common Examination (MCE) of the government secondary schools for the years 2011 and 2012 (see Table 5 for the contents of these tests).

Table 5

Items matching of NRT1 and NRT2

\begin{tabular}{|c|c|c|c|c|}
\hline \multicolumn{2}{|c|}{ Pre-test (NRT 1) } & \multicolumn{2}{|c|}{ Post-test (NRT 2) } & \multirow{2}{*}{ Concept(s) being assess } \\
\hline Item \# & Section & Item \# & Section & \\
\hline 1 & Part A & 1 & Part A & Word number and place value \\
\hline 2 & Part A & 9 & Part A & Subtraction \\
\hline 3 & Part A & 1 & Part B & Division \& multiplication \\
\hline 4 & Part A & 11 & Part A & Time \\
\hline 5 & Part A & 4 & Part A & Percentage \& division \\
\hline 6 & Part A & 2 & Part A & Sets/Venn diagram (Union and intersection) \\
\hline 7 & Part A & 10 & Part A & Elapsed time $\&$ subtraction of mixed-time units \\
\hline 8 & Part A & 8 & Part A & Lowest common multiple (LCM) \\
\hline 9 & Part A & 12 & Part A & Average \& division \\
\hline 10 & Part A & 13 & Part A & Probability \\
\hline 11 & Part A & 14 & Part A & Shapes \& rotation \\
\hline 12 & Part A & 7 & Part A & Number place value \\
\hline 13 & Part A & 5 & Part A & Subtraction \& division \\
\hline 14 & Part A & 15 & Part A & Financial - Multiplication \& division \\
\hline 15 & Part A & 6 & Part A & Angles (relation) \\
\hline 1 & Part B & 2 & Part B & Pattern-sequence \\
\hline 2 & Part B & 5 & Part B & Angles (size) \\
\hline 3 & Part B & 4 & Part B & Decimals - subtraction/multiplication/division \\
\hline 4 & Part B & 3 & Part A & Add \& subtract like terms \\
\hline 5 & Part B & 3 & Part B & Order of operations \\
\hline
\end{tabular}


The items that were used in the mathematics tests (NRT1 and NRT2) were mostly different in the pre-test and post-test but addressed the same content as judged by the first author and three Tongan mathematics teachers. The tests were then moderated by a panel of experienced mathematics teachers and one senior officer from the Tonga Examination Unit (TEU). Examples of matching items from the mathematics knowledge tests (NRT1 and NRT2) are shown in Figure 2.

\begin{tabular}{l|l}
\hline \multicolumn{1}{c|}{ NTR 1 } & \multicolumn{1}{c}{ NTR 2 } \\
\hline $\begin{array}{l}\text { Item 7. (Part A) } \\
\begin{array}{l}\text { Mele's presentation started at 9:25 am, she } \\
\text { finished at 10:12 am. How long did she do her } \\
\text { presentation? }\end{array}\end{array}$ & $\begin{array}{l}\text { Item 10. (Part A) } \\
\text { How long would Sione's flight be if it takes off at } \\
11: 15 \mathrm{pm} \text { and lands at 5:45am the next day? }\end{array}$ \\
$\begin{array}{l}\text { Item 14. (Part A) } \\
\begin{array}{l}\text { When some money was shared out equally } \\
\text { between 8 people, each person received \$9.00. If } \\
\text { the same amount was shared between 12 people, } \\
\text { how much money would each person receive? }\end{array}\end{array}$ & $\begin{array}{l}\text { Item 15. (Part A) } \\
\text { between 8 people, each person received \$9.00. If } \\
\text { the same amount was shared between 6 people, } \\
\text { how much money would each person receive? }\end{array}$ \\
\hline
\end{tabular}

Figure 2. Example of pre-test (NRT1) and post-test (NRT2) items

A Cronbach's alpha reliability analysis performed using SPSS (version 22) as a measure of internal consistency of the items in the NTRs for the experimental and comparison cohorts gave a coefficient of 0.60 both for NRT1 and NRT2. Ideally, a value of 0.6 or higher is considered satisfactory (Nunnally, 1978).

Students' Adaptive Learning Engagement (SALE). Since this study also investigated the effects of the CAME program on students' motivation and self-regulation, the Students' Adaptive Learning Engagement (SALE) instrument was employed in the study. The SALE instrument, adapted from Velayutham, Aldridge and Fraser (2011), was administered to both groups as a pre-test and a post-test. The purpose of this instrument was to investigate the changes of students' motivation and self-regulation in studying 
mathematics under the CAME program. The SALE instrument was validated with the data from a sample of 1,360 students in 78 classes across Grade 8, 9 and 10 in 10 public schools from the Perth metropolitan area. Although the SALE was developed and administered with science students, its lower reading level as well as its contents make it a good instrument to measure the motivation and self-regulation of students who learn mathematics in Tonga.

In this study, the SALE instrument was translated from English into the Tongan language to accommodate the language needs of some participants. The translating department of the Tonga Service Centre translated all the items of this instrument and it was cross checked by two English teachers from Liahona High School (LHS) to confirm the accuracy of the translation. Prior to the intervention, the modified SALE instrument (both English and Tongan versions) was piloted and tested with 47 Form 2 mathematics students from two secondary schools in Tonga. The purpose of this pilot study was to check the clarity and suitability of the SALE items and to eliminate ambiguities in the wording of the items. Based on the teachers' feedback, two items were re-worded to suit the students' vocabularies and understanding (see Figure 3). Due to some teachers teaching two subjects (for example, maths and science or maths and Tongan studies) for the same Form 2 students, item \# 24 was revised and included the word 'mathematics' to avoid confusion among the students.

\begin{tabular}{c|c|c}
\hline Item \# & Original item & Modified item \\
\hline 15 & What I have learn satisfies my curiosity & What I have learn satisfies my interest \\
24 & I am good at this subject & I am good at mathematics subject \\
\hline
\end{tabular}

Figure 3. Example of the revised items of the SALE instrument

The instrument consisted of four scales; learning goal orientation, task value, selfefficacy, and self-regulation. Learning goal orientation, task value, and self-efficacy are three components of motivation that have been consistently associated with students' adaptive motivational beliefs (Zimmerman \& Schunk, 2012), each of which is integral to successful 
engagement in self-regulated learning. Typical items in each scale are shown in Figure 4 (see Appendix 3 in the OSM for the entire instrument), with a 5-point Likert-type scale ranging from ' 1 ' for 'Strongly Disagree' to ' 5 ' for 'Strongly Agree'. The instrument was highly reliable with a Cronbach's alpha reliability of 0.94 in the pre-test and 0.93 in the post-test. The Cronbach's alpha values for the scales are summarised in Table 6.

\begin{tabular}{|c|c|}
\hline Learning Goal Orientation & Task Value \\
\hline $\begin{array}{l}\text { 1. One of my goal is to learn new mathematics } \\
\text { contents. } \\
\text { 2. One of my goal is to learn as much as I can. } \\
\text { 3. It is important to me that I improve my } \\
\text { mathematical skills. }\end{array}$ & $\begin{array}{l}\text { 1. What I learn is relevant to me. } \\
\text { 2. What I learn is of practical value. } \\
\text { 3. What I learn encourages me to think. }\end{array}$ \\
\hline Self-Efficacy & Self-Regulation \\
\hline $\begin{array}{l}\text { 1. I can figure out how to do difficult work. } \\
\text { 2. Even if the mathematics work is hard, I can } \\
\text { learn it. } \\
\text { 3. I can understand the contents taught. }\end{array}$ & $\begin{array}{l}\text { 1. Even when the tasks are uninteresting, I keep } \\
\text { working. } \\
\text { 2. I do not give up even when the work is } \\
\text { difficult. } \\
\text { 3. I keep working until I finish what I am } \\
\text { supposed to do. }\end{array}$ \\
\hline
\end{tabular}

Figure 4. SALE scales with example of the items

Table 6

Cronbach's alpha reliabilities for the scales of the SALE instrument

\begin{tabular}{lccc}
\hline \multirow{2}{*}{ Dimensions } & \multirow{2}{*}{$\begin{array}{c}\text { No. of } \\
\text { items }\end{array}$} & \multicolumn{2}{c}{ Cronbach's alpha reliability } \\
\cline { 3 - 4 } & 8 & Pre-test & Post-test \\
\hline Learning Goal Orientation & 8 & 0.86 & 0.84 \\
Task Value & 8 & 0.85 & 0.85 \\
Self-efficacy & 9 & 0.85 & 0.83 \\
Self-regulation & & 0.83 & 0.84 \\
\hline
\end{tabular}




\section{Students' interviews}

Part of the data collection involved conducing semi-structured interviews with 12 students from the Experimental group and 4 students from the Comparison group. The purpose of using interviews in this study is to get more in-depth information on the perceptions of the students. All students' interviews were audio-recorded and fully transcribed. The interviews were analysed through repeated reading of the transcripts as well as repeated listening to the audiotapes to identify themes and ideas that were relevant to the research question and to provide insight into the quantitative data (Creswell, 2012). Excerpts from the transcripts was selected for this paper have been included to illustrate the students' perceptions toward the CAME program as well as their learning of mathematics. Three methods were used to enhance the accuracy of the interview analysis: (1) researcher triangulation, (2) memberchecking, and (3) engaging another $\mathrm{PhD}$ student to critically question the researcher's coding and analysis. In regard to method number (3), the researcher analysed the data independently and then allowed another $\mathrm{PhD}$ student to re-evaluate and reflect on the analysis as a form of researcher triangulation.

\section{Results}

\section{Students' Performance on the Numeracy Reasoning Tasks 1 and 2 (NRTs)}

The results included in this section are in response to the Research Question 1: To what extent does the CAME program change Tongan Form 2 students' academic achievement in mathematics. An independent samples t-test analysis (see Table 7) showed that there were initially no significant differences between the experimental group and the comparison group for students' performance on the NRT1 pre-test (prior to the CAME intervention). However, there was a statistically significant difference in the post-test with the students in the experimental group scoring a higher mean than the comparison group. In terms of cognitive 
gains, the students in the experimental schools started at a lower mean cognitive level than their counterparts in the comparison school, but in the post-test they made greater cognitive gains over the intervention period, with an effect size of 2.04. According to Cohen (1988), this effect size indicated a very large effect on the students who participated in the CAME program. The results suggest that the CAME program was successful in improving students' understanding of these mathematical concepts as well as in advancing the cognitive ability of mathematics students in the experimental groups.

Table 7

Independent samples t-tests of pre-test and post-test for the NRTs $(N=338)$

\begin{tabular}{|c|c|c|c|c|c|c|}
\hline & \multicolumn{2}{|c|}{$\begin{array}{l}\text { Experimental group } \\
\qquad(\mathrm{N}=219)\end{array}$} & \multicolumn{2}{|c|}{$\begin{array}{l}\text { Comparison group } \\
\qquad(\mathrm{N}=119)\end{array}$} & \multirow{2}{*}{ t-value } & \multirow{2}{*}{$p$} \\
\hline & Mean & SD & Mean & SD & & \\
\hline Pre-test (NRT1) & 10.24 & 4.94 & 11.31 & 6.56 & 1.70 & 0.09 \\
\hline Post-test (NRT2) & 22.11 & 6.57 & 15.83 & 5.11 & $9.04^{* * * *}$ & 0.001 \\
\hline Mean gain & \multicolumn{2}{|c|}{11.87} & \multicolumn{2}{|c|}{4.52} & & \\
\hline Effect size (Cohen's $d$ ) & \multicolumn{2}{|c|}{2.04} & \multicolumn{2}{|c|}{0.77} & & \\
\hline
\end{tabular}

\section{Students' Motivation and Self-Regulation Levels}

This section describes the answer to Research Question 2: What are the Year 8 (Form 2) students' motivation and self-regulation levels when participating in the learning of mathematics in the CAME program? An independent samples t-test was conducted to compare the differences in the learning motivation and self-regulation of the experimental and comparison group students and the results are presented in Tables 8 and 9.

There were statistically significant differences between the pre-test and post-test mean scores of the four scales of the SALE instrument for students in the experimental group. The post-test means scores of all the four scales were significantly higher than the pre-test mean scores of the equivalent scales, suggesting that the CAME program was effective in 
improving the students' motivation and self-regulation levels (see Table 8). Note that in this study, motivation is described by its three components: learning goal orientation, task value, and self-efficacy (Zimmerman, 2002).

Table 8

SALE pre-test and post-test comparison for students in the CAME program $(N=219)$

\begin{tabular}{|c|c|c|c|c|c|c|}
\hline \multirow{2}{*}{ Scale of SALE } & \multicolumn{2}{|c|}{ Pre-test } & \multicolumn{2}{|c|}{ Post-test } & \multirow{2}{*}{$\mathrm{t}$-value } & \multirow{2}{*}{$\begin{array}{l}\text { Effect size } \\
\text { (Cohen's } d \text { ) }\end{array}$} \\
\hline & Mean & $\mathrm{SD}$ & Mean & $\mathrm{SD}$ & & \\
\hline $\begin{array}{l}\text { Learning Goal } \\
\text { Orientation }\end{array}$ & 4.26 & 0.67 & 4.53 & 0.47 & $5.70^{* * *}$ & 0.47 \\
\hline Task Value & 4.04 & 0.77 & 4.46 & 0.46 & $7.81^{* * * *}$ & 0.66 \\
\hline Self-efficacy & 3.93 & 0.81 & 4.32 & 0.51 & $6.30^{* * * *}$ & 0.58 \\
\hline Self-regulation & 4.00 & 0.74 & 4.42 & 0.44 & $7.86^{* * *}$ & 0.70 \\
\hline
\end{tabular}

In contrast, there were no statistically significant difference in the post-test scores among students in the comparison group. The post-test mean scores for three scales were lower than the pre-test mean scores while one scale (Learning goal orientation) had a small increase in the post-test score but the difference was not statistically significant (see Table 9). The results suggest that the traditional instructional program that was implemented with the comparison group had no effect in enhancing the students' motivational and self-regulation levels in learning mathematics.

Table 9

SALE pre-test and post-test comparisons for students in the comparison group $(N=119)$

\begin{tabular}{ccccccccc}
\hline \multirow{2}{*}{ Scale of SALE } & \multicolumn{2}{c}{ Pre-test } & & \multicolumn{2}{c}{ Post-test } & & & \\
\cline { 2 - 3 } & Mean & SD & & Mean & SD & & & \\
\hline $\begin{array}{c}\text { Learning Goalue } \\
\text { Orientation }\end{array}$ & 4.40 & 0.69 & & 4.42 & 0.59 & 0.31 & 0.760 \\
Task Value & 4.35 & 0.71 & & 4.31 & 0.64 & -0.44 & 0.664 \\
Self-efficacy & 4.33 & 0.62 & & 4.21 & 0.63 & -1.47 & 0.144
\end{tabular}




\begin{tabular}{lllllll} 
Self-regulation & 4.35 & 0.56 & 4.24 & 0.56 & -1.55 & 0.124 \\
\hline
\end{tabular}

\section{Students' Interview Responses}

Twelve students from the experimental schools were interviewed regarding their participation in the CAME program. Most of these students (more than 80\%) mentioned that they enjoyed the CAME activities and their teacher's support that they had received. Among the students' responses were the following positive comments:

"This year I enjoyed going to my maths class. We usually did fun and interesting activities."

"My teacher this year was also my maths teacher last year in Form 1, but the way she taught us this year was much different from what I experienced last year. This year she's fun and she always helped and supported me every time I asked a question.” "We mostly worked in groups... We shared ideas, we argued sometimes, but at the end we were able to understand."

The students noted that the CAME program positively influenced their learning experience and interaction with the teachers. They also mentioned the changes in their learning attitudes such as self-determination, confidence, self-regulation, and desire for success.

"Some activities were hard for me but I tried to solve them."

"I'm not really strong in mathematics, but I always went to that class. I liked what we were doing there and I liked the teacher."

"I do believe that I will get a better grade this year."

However, a minority (less than $20 \%$ ) of students had different views:

"Most of the time I didn't understand what we were doing in class...I didn't like some of the activities because they were so difficult for me." 
"I can't tell the difference between what I did last year and the things we did this year."

At the comparison school, four students were interviewed with regards to their learning of the regular mathematics curriculum, and also reflect on the teaching strategies of their teachers. Their responses were critical of their teachers' way of teaching. Below are few of the students' answers.

"My goal is to do better in mathematics this year, but I can't because I hardly understand the way my teacher's teaching."

"I like working in a group. We always work in groups in my science class. But in my maths class, we never do that. We mostly copy notes from the board and work individually."

Overall, the interview data seem to support some of the findings from the quantitative data. In the interviews, the CAME group students revealed that they had gained more positive attitudes towards their learning mathematics which led to better engagement in their work and better mathematics performance.

\section{Classroom Observations: Experimental and Comparison Group Classrooms.}

The main features of the CAME intervention program focused on formal reasoning patterns and the use of the five 'pillars' of CAME in the lessons. The teachers in the experimental schools who attended the CAME professional development workshops were visited by the first author regularly during the intervention period. It has been observed that students in the CAME classes were provided with worksheets and cards (in most activities), and they also had more practical work than during their regular mathematics lessons; this is not normally the case in mathematics classes in Tonga. In the comparison school classes, teaching was mainly textbook-oriented. The teachers explained the topics from the front of the classroom 
for about 10 - 15 minutes, then they assigned some exercises from the textbook for the students to solve.

In the CAME classrooms, teachers used team teaching or group work and there were more teacher-student, student-student interactions and discussions than was normally the case. On the other hand, the comparison school classes were using normal mathematics teaching which is 'chalk and talk' and students mostly worked individually with their own textbook. During whole-class discussion sessions, the students in the CAME classrooms were very active and engaged in discussions. They posed a lot of questions to the teachers and to their classmates as they presented their group work results. In the comparison school, on the other hand, discussion sessions were not supported by the students who were not engaged or were too shy to share their results with the rest of the class.

With regards to students' learning under the five working principles (or pillars) of cognitive acceleration, students easily adapted the natures of cognitive preparation, cognitive conflict, construction as well as bridging in their problem solving and classroom learning activities. The metacognition component, however, was not easily adopted by the students at the beginning of the intervention. Students were not used to monitoring their own thinking during class activities and they often had difficulties structuring their thoughts. The first author often heard students say 'I don't know where to begin' or 'I don't think my answer is correct but I don't know what else to do'. As time went by, students became familiar with the CAME procedures and learned how to resolve such procedural difficulties. Simply, they learned to share ideas by listening to other students and describing their own thoughts to others. By the end of the intervention, it was observed that the majority of the students in the CAME schools had the ability to regulate and monitor their own cognitive activities and reflect on their actions while engaged in problem solving. 


\section{Discussion}

Results from the CAME intervention in these experimental schools show positive effects on students' mathematics achievement, attitudes, and levels of thinking, compared with students from the comparison school. The Numeracy Reasoning Tasks (NRTs) indicated that students in the experimental schools made significant cognitive gains over the eight months of the intervention. These students had started with lower scores prior to the intervention, but their final scores in the post-test were much higher compared to the comparison cohort. The overall effect size of 2.04 for the NRTs indicates that the CAME intervention with its professional development and classroom lesson activities was highly successful. While these results demonstrated that the intervention program helped improve the students' mathematical thinking levels, it remains to be seen whether the cognitive gains made by this cohort of students will be translated into improved academic performance in their later school years; this will be the subject of further research.

The independent samples $t$-test results (see Tables 8 and 9) revealed that students who participated in the CAME intervention were found to have somewhat more positive attitudes toward mathematics than the students from the non-CAME group. The students in the CAME intervention schools perceived more teacher support and were involved in more activity tasks than the comparison school students. These data seem to suggest positive associations between learning attitudes (shown in Tables 8 and 9) and academic achievement (shown in Table 7). Compared to the students from the comparison group, the experimental group students had lower pre-test scores in the NRT1 and SALE, but after the CAME intervention, they showed great improvement in their academic performance and attitudes. This finding is consistent with the studies conducted by Mega, Ronconi and De Beni (2014), Velayutham, et 
al. (2011) and Wolters (1999), who argued that motivational beliefs and self-regulation based learning have a positive significant relationship with academic performance.

Looking at the findings of this study, it is relevant to consider how such improvements in students' thinking are brought about. The 16 selected lesson activities were developed to give rise to classroom work focused directly within the five 'reasoning patterns'. Cognitive conflict drove the discussion, while metacognition and problem solving dominated as the students were working together on the lesson activities. These instructional strategies when used together have the capacity to improve the reasoning ability of the students. For the CAME lessons, the role of the teacher changed from director to a facilitator of learning activities. During the whole-class or group discussions, the teacher prompted students to consider the ideas that emerged from their earlier discussion or questions, to ascertain whether or not there were other ways of looking at the problem or the data. Teachers were not required to provide all the answers to students' questions but to facilitate and encourage students to explore together possible solutions for given tasks.

Students reflecting on their participation in the CAME intervention revealed that they may have become more confident that they could do better in mathematics although it is a difficult subject to learn. They were more confident working with challenging activities, were better listeners, and more capable of internalising the concepts articulated in lessons.

With the results and improvements that have been recorded in this study, we can speculate that the keys to success of the CAME program in Tongan classrooms are the cognitive conflicts set with specific reasoning patterns for each lesson, the pedagogy that fosters the discussion of ideas in student groups and metacognition. These instructional strategies have the capacity to improve the reasoning ability of the students which leads to better performance. However, the findings raise concerns about the current teaching 
approaches of the teachers and the curriculum that they employ in mathematics classrooms in Tonga.

As mentioned earlier, the goal of the CAME program in Tonga, through its rich pedagogy and thinking activities, is to develop formal operational thinking by improving students' academic performance in mathematics regardless of their maturation, mathematics background or schooling. The findings of this study show that the interventions in the CAME program can make a difference to students' thinking skills and cognitive capacity, leading to their improved academic achievement as well as improved learning attitudes by being selfregulated and motivated.

\section{References}

Adey, P. (1999). The science of thinking, and science for thinking: A description of cognitive acceleration through science education (CASE) (Innodata Monographs 2). Geneva: International Bureau of Education.

Adey, P., Hewitt, G., Hewitt, J., \& Laudau, N. (2004). The professional development of teachers: Practice and theory. Boston: Kluwer.

Adey, P., Robertson, A., \& Venville, G. (2002). Effects of a cognitive acceleration programme on year I pupils. British Journal of Educational Psychology, 72(1), 1-25.

Adey, P., \& Shayer, M. (1990). Accelerating the development of formal thinking in middle and high school students. Journal of Research in Science Teaching, 27(3), 267-285.

Adey, P., \& Shayer, M. (1993). An exploration of long-term far-transfer effects following an extended intervention program in the high school science curriculum. Cognition and Instruction, 11(1), 1-29.

Adey, P., \& Shayer, M. (1994). Really raising standards : Cognitive intervention and academic achievement. Florence, KY: Routledge.

Adey, P., Shayer, M., \& Yates, C. (1989). Thinking science: The curriculum materials of the CASE project (1 ed.). London: Nelson.

Adey, P., Shayer, M., \& Yates, C. (2001). Thinking Science: The curriculum materials of the CASE project (3rd ed.). London: Nelson.

Adhami, M., \& Shayer, M. (2007). Thinking maths: Cognitive acceleration in mathematics education (CAME). Oxford, England: Heinemann Educational Books.

Aunio, P., Hautamäki, J., \& Van Luit, J. E. H. (2005). Mathematical thinking intervention programmes for preschool children with normal and low number sense. European Journal of Special Needs Education, 20(2), 131-146.

Backwell, J. L., \& Hamaker, T. (2003). Cognitive acceleration through technology education (CATE). Taunton, England: Nigel Blagg Associates.

Cohen, J. (1988). Statiscal power analysis for the behavioural sciences. (2 ed.). Hillsdale, NJ: Erlbaum. 
Cohen, L., Manion, L., \& Morrison, K. (2011). Research methods in education (7th ed.). New York: Routledge.

Creswell, J. W., \& Clark, V. (2008). Designing and conduction mixed methods research. Thousand Oaks, CA: Sage Publications.

Creswell, J. W. (2012). Educational research : planning, conducting, and evaluating quantitative and qualitative research (4th ed.. ed.). Boston: Pearson.

Fasi, U. M. L. (1999). Bilingualism and learning mathematics in English as a second language in Tonga. (Unpublished doctoral dissertation), University of Reading, Reading, England.

Frith, C. D. (2012). The role of metacognition in human social interactions. Philosophical Transactions of the Royal Society, B: Biological Sciences, 367(1599), 2213-2223.

Hong, A. W. C. (2010). Applying cognitive conceptual approach in developing year 6 pupils' problem solving skills in mathematics. Pertanika Journal of Social Science and Humanities, 18, 15-35.

Kerridge, S. (2010). A study into the improvement in the mathematical academic attainment of low attainers in year 7 (11-12 year olds) when accelerated learning is used as a teaching pedagogy in the classroom. (Unpublished doctoral dissertation), Durham University, Durham, England.

Leo, E. L., \& Galloway, D. (1996). Conceptual links between cognitive acceleration through science education and motivational style: A critique of Adey and Shayer.

International Journal of Science Education, 18(1), 35-49.

Manu, S. (2005). Mathematical understanding and Tongan bilingual students' language switching: Is there a relationship? (Unpublished doctoral dissertation), University of British Columbia, Vancouver, Canada.

Maume, K., \& Matthews, P. (2000). A study of cognitive accelerated learning in science. Irish Educational Studies, 19(1), 95-106.

McGregor, D., \& Gunter, B. (2001). Changing pedagogy of secondary science teachers: the impact of a two-year professional development programme. An International Journal of Teachers' Professional Development, 5(1), 59-74.

Mega, C., Ronconi, L., \& De Beni, R. (2014). What makes a good student? How emotions, self-regulated learning, and motivation contribute to academic achievement. Journal of Educational Psychology, 106(1), 121-131.

Ministry of Education and Training, T. (2014). Report of the ministry of education and training for 2013, Tonga. Nukualofa, Tonga: Ministry of Education and Training, Tonga.

Mok, I., \& Johnson, D. (2000). Reasoning algebraically with IT: A cognitive perspective. Mathematics Education Research Journal, 12(3), 286-302.

Nunnally, J. C. (1978). Psychometric theory (2 ed.). New York: McGraw-Hill.

Olaoye, A. A. (2012). Cognitive acceleration in mathematics education lesson (CAMEL) in Nigeria. British Journal of Humanities and Social Sciences (BJHSS), 3(2), 77-86.

Pekrun, R. (1992). The impact of emotions on learning and achievement: Towards a theory of cognitive/motivational mediators. Applied Psychology, 41(4), 359-376.

Pintrich, P. R. (2000). The role of goal orientation in self-regulated learning. In M. Boekaerts, P. R. Pintrich \& M. Zeider (Eds.), Handbook of self-regulation (pp. 451-502). San Diego, CA: Academic Press.

Pohiva, S. (2014). An outcomes-based assessment reporting approach for enhancement of teaching and learning in the Pacific islands. In R. Toumu'a (Eds), Proceedings of the Vaka Pasifika Educational conference 2014. Nukualofa, Tonga (pp 125-135). University of the South Pacific. 
Shayer, M. (2003). Not just Piaget; not just Vygotsky, and certainly not Vygotsky as alternative to Piaget. Learning and Instruction, 13(5), 465-485.

Shayer, M, \& Adhami, M. (2007). Fostering cognitive development through the context of mathematics: Results of the CAME project. Educational Studies in Mathematics, 64(3), 265-291.

Shayer, M., \& Adhami, M. (2010). Realizing the cognitive potential of children 5-7 with a mathematics focus: Post-test and long-term effects of a 2-year intervention. British Journal of Educational Psychology, 80(3), 363-379.

Tatafu, M., Booth, E., \& Wilson, M. (2000). Secondary school failure in Tonga: Implications for in service and pre service teacher development. Directions: Journal of Educational Studies, 19(1), 55-81.

Uata, T. (2002). Comparative effectiveness of high schools in Tonga's education system: A production function approach. (Unpublished master thesis), California State University, Fullerton, CA.

Velayutham, S., Aldridge, J., \& Fraser, B. (2011). Development and validation of an instrument to measure students' motivation and self-regulation in science Learning. International Journal of Science Education, 33(15), 2159-2179.

Vivier, E. D. (2013). Opening schooling programmes for the Kingdom of Tonga: Report of a short-term consultancy. Vancouver, Canada: Commonwealth of Learning.

Vygotsky, L. S. (1986). Thought and language. Cambridge, MA: MIT Press.

Wolters, C. A. (1999). The relation between high school students' motivational regulation and their use of learning strategies, effort, and classroom performance. Learning and Individual Differences, 11(3), 281-299.

Zimmerman, B. J. (2002). Becoming a self-regulated learner: An overview. Theory into Practice, 41(2), 64-70.

Zimmerman, B. J., \& Schunk, D. H. (2012). Motivation: An essential dimension of selfregulated learning Motivation and Self-regulated learning: Theory, research and applications (pp. 1-30). New York: Lawrence Erlbaum Associates. 